\title{
PREFERENSI ARTHROPODA TERHADAP TUMBUHAN LIAR DI AREA KEBUN TEH AFDELING WONOSARI, SINGOSARI KABUPATEN MALANG
}

\author{
Raras Setyo Retno \\ Program studi pendidikan Biologi FPMIPA IKIP PGRI Madiun \\ email : rarassetyo86@gmail.com
}

Diterima 5 September 2014 disetujui 7 November 2014

\begin{abstract}
The role of insects (arthropods) in human life can affect the yield and quality of agricultural products. Insect pests are insects that regularly or occasionally cause damage that can reduce the yield or quality of agricultural products. The purpose of this study was to determine the preference of arthropods on wild plants, to compare the percentage of interest and time orientation of arthropods on wild plants. This research is a qualitative descriptive that tries to reveal and explain about the preferences or interests arthro in Poda against wild plants (weeds) Cambodgien Wonosari Tea Garden Area, Singosari Malang. The difference in the percentage interest in insects against wild plants affected by volatile compounds secreted by wild plants. Overall plant contain volatile compounds produced by the leaves, flowers or fruit of the wild plants cause differences insect attraction. Insects itself able to select and respond to volatile compounds from plants that are in nature can be visited.
\end{abstract}

Keywords : insects, arthropods, wild plants.

\section{PENDAHULUAN}

Petani sering mengalami kendala dalam mengolah dan memelihara sawah atau kebunnya. Salah satu permasalahan yang sering dihadapi oleh petani yaitu serangan organisme pengganggu tanaman (OPT). Pada awalnya pengendalian hama dilakukan secara sederhana, yaitu secara fisik dan mekanik menggunakan alat sederhana seperti dengan alat pemukul. Semakin luasnya daerah pertanian membuat cara-cara sederhana (fisik dan mekanik) tidak lagi mampu membendung peningkatan populasi hama. Seiring dengan perkembangan IPTEK, para pakar hama menemukan dan mengembangkan banyak metode dan teknik pengendalian hama yang lebih efektif (Untung, 1993).

Pemanfaatan musuh alami hama tanaman, khususnya parasitoid dan predator merupakan salah satu komponen Pengendalian hama Terpadu (PHT) yang ramah lingkungan. Jenis serangga yang digunakan dalam PHT dapat bermacammacam tergantung dari sifat serangga yang digunakan. Jenis serangga yang digunakan biasanya memiliki sifat sebagai serangga parasitoid atau serangga predator (Martono, 2008). Musuh alami sebagai salah satu komponen ekosistem yang sangat menentukan keseimbangan populasi hama, perlu diberi peluang atau suasana untuk berfungsi secara maksimal (Untung, 1993 dalam Prasetia, 2002).

Peranan serangga (Arthropoda) dalam kehidupan manusia dapat mempengaruhi hasil dan kualitas hasil pertanian. Serangga hama yang merupakan jenis serangga yang secara rutin atau kadang-kadang menyebabkan kerusakan sehingga dapat mengurangi hasil atau kualitas hasil pertanian. Selain itu ada juga jenis serangga penyerbuk yang dapat membantu manusia dalam penyerbukan tanaman. Sejumlah serangga juga ada yang berperan sebagai predator dan parasit dari beberpa jenis hama tanaman, serangga jenis ini dapat digunakan sebagai pengendalian hama tanaman, khususnya pada tanaman gulma yang merugikan (Jumar, 2000).

Usaha yang dilakukan untuk meningkatkan keberadaan musuh alami/ predator adalah dengan menyediakan habitat yang sesuai dan disukai untuk 
perkembangannya. Untuk itu, menurut Prasetia (2002) perlu adanya konservasi predator di agroekosistem untuk meningkatkan efektifitas potensinya dalam mengendalikan populasi hama dengan menciptakan mikrohabitat tersebut, yang sesuai untuk melakukan aktifitas reproduksi, mendapatkan makanan alternatif, tempat hinggap dan persinggahan sementara. Tanaman yang disukai musuh alami ini seringkali sebagai tanaman liar dan dikategorikan sebagai gulma, yaitu tanaman liar yang mengganggu pertaniann (Harahap dan Tjahyono, 1994 dalam Kholishotin, 2002).

Tumbuhan liar biasanya tumbuh secara alami di tempat-tempat yang tidak mengalami gangguan. Jenis-jenis ini mendominasi di segala tempat dengan cepat, dan jika tidak mengalami gangguan jenis-jenis ini akan bermunculan silih berganti sehingga tercapainya populasi yang stabil dalam keadaan setimbang (Sastroutomo, 1990). Tumbuhan liar terbukti sangat penting untuk meningkatkan keanekaragaman serangga di ekosistem pertanian Adapun tujuan dari penelitian ini adalah Untuk mengetahui preferensi arthropoda terhadap tumbuhan liar, Untuk mengetahui perbandingan presentase ketertarikan dan waktu orientasi arthropoda terhadap tumbuhan liar.

\section{METODE}

Jenis penelitian ini adalah deskriptif kualitatif dengan yang mencoba mengungkapkan dan memaparkan tentang preferensi atau ketertarikan arthropoda terhadap tumbuhan liar (gulma) di Area Kebun Teh Afdeling Wonosari, Singosari Kabupaten Malang.

Objek dalam penelitian ini adalah beberapa jenis serangga yang menghampiri tumbuhan liar pada antara lain Datura metel, Tridax procumbens, Blumea lacera, Centella asiatica, dan Emilia sonchifolia. Dalam penelitian ini indikator yang diambil adalah beberapa jenis serangga dan waktu yang diperlukan serangga untuk mengenali bau dari tumbuhan liar (gulma) yang disukainya. Pendugaan jenis gulma yang cenderung menarik bagi serangga didasarkan atas besarnya persentase ketertarikan terhadap jenis tumbuhan liar (gulma) tertentu, sedangkan waktu hanya merupakan parameter pembantu dalam menentukan persentase ketertarikan serangga terhadap tumbuhan liar (gulma) tersebut. Pengamatan dilakukan di area kebun teh afdeling Wonosari Singosari Malang selama tiga hari berturut-turut pada jam yang sama yaitu dimulai pada pukul 08.00 WIB.

Alat yang digunakan pada proses pengambilan data penelitian ini adalah sebagai berikut. Kamera digital: Alat tulis: Gambar dokumentasi serangga adapun bahan yang digunakan dalam pengamatan ini adalah lima tumbuhan liar yaitu Datura metel, Tridax procumbens, Blumea lacera, Centella asiatica, dan Emilia sonchifolia. Observasi dilakukan pada lokasi yang dimaksudkan sebagai tempat pencuplikan sampel dengan keadaan vegetasi yang banyak didominasi oleh tumbuhan liar. Teknik pengumpulan data dalam penelitian ini dilakukan dengan cara pengmabilan data dengan 3 ulangan tiap 1 tumbuhan amatan dengan 1 periode.

\section{HASIL DAN PEMBAHASAN}

Berdasarkan pengamatan yang telah dilakukan di Area Kebun Teh Afdeling Wonosari, Singosari Kabupaten Malang, maka didapatkan hasil pada tabel 1 sebagai berikut. 
Retno

Tabel 1. Hasil Pengamatan Serangga yang Ditemukan pada Beberapa Tumbuhan Liar

\begin{tabular}{|c|c|c|c|c|c|c|}
\hline \multirow[b]{2}{*}{ Hari } & \multirow{2}{*}{$\begin{array}{c}\text { Serangga yang } \\
\text { ditemukan } \\
\text { (Genus) }\end{array}$} & \multicolumn{5}{|c|}{ Tanaman } \\
\hline & & $\begin{array}{l}\text { Centella } \\
\text { asiatica }\end{array}$ & $\begin{array}{c}\text { Tridax } \\
\text { procumbens }\end{array}$ & Datura metel & Emilia sp. & $\begin{array}{l}\text { Blumea } \\
\text { lacera }\end{array}$ \\
\hline \multirow{10}{*}{1} & Andralus & & & & 1 & \\
\hline & Tettigoniidae & 4 & 2 & & & \\
\hline & Atractomorpha & 2 & & 1 & & 1 \\
\hline & Harmonia & 2 & 4 & 1 & & \\
\hline & Henosepilachna & & 3 & 7 & & 3 \\
\hline & Menochilus & & & 2 & & \\
\hline & Locusta sp. 1 & 2 & & & & 1 \\
\hline & Locusta sp. 2 & & & & & \\
\hline & Monomorium & 7 & 1 & & & 5 \\
\hline & Lycosa sp. 2 & & & 1 & 2 & \\
\hline \multirow{9}{*}{2} & Andralus & & & & & \\
\hline & Tettigoniidae & 5 & 2 & 3 & 2 & \\
\hline & Atractomorpha & 2 & & & & 2 \\
\hline & Harmonia & & 4 & 3 & & 1 \\
\hline & Henosepilachna & & 2 & 13 & & 2 \\
\hline & Menochilus & 3 & & & & \\
\hline & Locusta sp. 1 & & & & & \\
\hline & Locusta sp. 2 & 2 & 1 & & 1 & \\
\hline & $\begin{array}{l}\text { Monomorium } \\
\text { Lycosa sp. } 2\end{array}$ & 5 & & 4 & & 3 \\
\hline \multirow{9}{*}{3} & Andralus & & & & & \\
\hline & Tettigoniidae & 6 & 2 & 2 & 3 & \\
\hline & Atractomorpha & 1 & & & & 1 \\
\hline & Harmonia & 4 & 4 & 3 & & \\
\hline & Henosepilachna & & 4 & 10 & & 5 \\
\hline & Menochilus & 1 & 2 & 2 & & 2 \\
\hline & Locusta sp. 1 & 2 & & & & \\
\hline & Locusta sp. 2 & & & & 2 & \\
\hline & Monomorium & 3 & & 7 & & 5 \\
\hline
\end{tabular}

Berdasarkan hasil pengamatan yang ada pada tabel di atas menunjukkan bahwa serangga yang menghinggapi tanaman tidaklah sama, tetapi ditemukan pula beberapa serangga yang sama pada tanaman lain. Hal tersebut menunjukkan bahwa setiap tanaman memiliki senyawa kimia yang berbeda-beda dan serangga mampu memilih dan merespon senyawa tersebut. Pengamatan dilakukan selama tiga hari, hewan yang datang menghinggapi tumbuhan juga tidak menetap. Jumlah hewan yang sama bisa bertambah atau berkurang bahkan tidak lagi menghinggapi tumbuhan tersebut. Pada beberapa tanaman, ditemukan hewan baru pada pengamatan hari kedua maupun ketiga.

Perbedaan presentase ketertarikan serangga terhadap tanaman liar dipengaruhi oleh senyawa-senyawa volatil yang disekresikan oleh tumbuhan liar. Menurut Yanuwiadi et.al (2011) tumbuhan secara keseluruhan mengandung senyawa volatil yang dihasilkan daun, bunga ataupun buah dari tumbuhan liar tersebut menyebabkan perbedaan ketertarikan serangga. Serangga sendiri mampu memilih dan merespon senyawa volatil dari tumbuhan yang memang di alam bisa dikunjungi. Menurut Sutisna (1988) senyawa sekunder yang 
cepat menguap (volatil) berperan sebagai semiokimia yang berperan khusus dalam penyerbukan dan pencarian makan oleh serangga. Aroma dari tumbuhan mendominasi lingkungan kimia atmosfir yang ada pada komunitas darat dimana ratusan tumbuhan menciptakan suatu ruang aktif bersifat khusus tetapi saling tumpang tindih. Berdasarkan senyawa tertentu serangga mampu memilih tanaman yang cocok untuk merangsang pola yang mengarah pada peletakan telur, sumber makanan yang sesuai, tempat berkumpul untuk menemukan lawan jenis dan untuk berlindung.

Menurut Dethier (1963 dalam Nandini, 2002) intensitas senyawa kimia sangat mempengaruhi respon bau. Bau dari iso-valeraldehyde pada konsentrasi dibawah ambang bau yang spesifik akan memikat musca, sebaliknya semakin tinggi konsentrasi akan berlaku sebagai repellent baginya. Respon serangga terhadap suatu senyawa kimia dimulai dari organ antena serangga. Serangga menggunakan kemampuan khemoresepsi dalam mencari habitat alternatifnya memiliki antena yang sensitif terhadap senyawa tertentu.

Untung (1993) menyatakan bahwa komunikasi dengan lingkungannya berlangsung dengan perantara senyawa kimia diantaranya kairomon dan allomon. Kairomon merupakan senyawa kimia yang dapat menarik kedatangan serangga. Ketertarikan serangga dimulai ketika seranggamenerimasatuataulebihsinyaldari tanaman. Kelangsungan dari suatu makhluk hidup tergantung pada kemampuannya untuk merasakan rangsangan-rangsangan dari luar dan bereaksi sesuai rangsangan tersebut (Widiastuti, 2000). Serangga mampu mendeteksi informasi tentang lingkungannya melalui indera yang merupakan fungsi dari bermacam-macam organ sensilia seperti mekanoreseptor, khemoreseptor, thermoreseptor, sound reseptor dan fotoreseptor (Ross, 1982 dalam Turista, 2011).

Yanuwiadi(2006) menyatakan bahwa respon serangga terhadap rangsangan bau yang dikeluarkan oleh tanaman dimulai dengan pengenalan terhadap bau, proses pengenalan tersebut ditandai dengan berubahnya antena serangga untuk mencari arah sumber bau, kemudian serangga akan mengitari bilik udara sehingga serangga menemukan bau yang paling disukai. Proses respon serangga terhadap senyawa kimia terdiri dari 1) mengisolasi dan mengidentifikasi struktur dari senyawa kimia, 2) menginisiasi respon terhadap kairomon dan 3) memperlihatkan respon yang sesuai dengan konsentrasi kairomon dalam bentuk perilaku (Frengkel, 1959 dalam Metclaf dan Metcalf, 1992)

Serangga tertarik dan memanfaatkan suatu tumbuhan tertentu karena adanya senyawa kairomon yang dihasilkan oleh tumbuhan tersebut. Menurut Metcalf dan Metcalf (1992) hampir seluruh daun, buah, dan bunga mengandung senyawa koiromon. Senyawa koiromon yang dihasilkan oleh tumbuhan tersebut akan mempengaruhi keputusan serangga dalam memilih jenis tanaman yang akan dikunjunginya. Mudjiono (1998) mengatakan bahwa beberapa senyawa sekunder tumbuhan bertindak sebagai tanda bagi serangga dalam memilih dan memakan tumbuhan. Senyawa tumbuhan tersebut dapat berperan sendiri atau dapat juga diperkuat oleh nutrisi yang ada pada tumbuhan. Kekhususan senyawa koiromon tumbuhan tertentu maka serangga dapat mendeteksi keberadaan jenis tumbuhan yang disukainya.

Serangga memberikan respons yang berbeda-beda terdapat setiap jenis stimulant yang diterimanya. Kebiasaaan dalam menanggapi respon ini akan membentuk perilaku serangga dalam banyak hal termasuk proses pemcarian makanan dan oviposisi. Menurut Hufaker dan Mesenger (1989) penglihatan dan kemoteresepsi merupakan dua indera utama yang membimbing predator ke habitat yang banyak mengandung mangsa atau makanan-makanan lainnya. Metcalf dan Metcalf (1992) menyatakan bahwa hamper seluruh daun, buah, dan bunga pada tumbuhan mengandung 30-80 \% atau lebih komponen volatile yang terdiri dari tipe dan struktur kimia yang beragam. Berdasarkan hasil penelitian Van der 
Pers (1981) dalam Metcalf dan Metcalf (1992), diketahui bahwa serangga mampu merespon senyawa volatile tumbuhan yang disukainya yang merupakan habitat alternatifnya karena tingginya sensitivitas pada organ reseptor penciumannya.

\section{SIMPULAN}

Simpulan yang bisa ditarik dari kegiatan pengamatan ini yaitu. Perbedaan presentase ketertarikan serangga terhadap tanaman liar dipengaruhi oleh senyawasenyawa volatil yang disekresikan oleh tumbuhan liar. Proses respon serangga terhadap senyawa kimia terdiri dari 1) mengisolasi dan mengidentifikasi struktur dari senyawa kimia, 2) menginisiasi respon terhadap kairomon dan 3) memperlihatkan respon yang sesuai dengan konsentrasi kairomon dalam bentuk perilaku. Tumbuhan liar yang dipilih oleh serangga tertentu dapat digunakan sebagai sumber pakan alternatif atau sebagai habitat alternatif. Habitat alternatif adalah habitat sekitar lahan pertanian atau perkebunan yang merupakan tempat pengungsian bagi banyak serangga predator dan parasitoid, jika kondisi di lahan pertanian atau pertamanan berubah drastis seperti waktu panen. Berdasarkan senyawa tertentu, serangga mampu memilih tanaman yang cocok untuk merangsang pola yang mengarah pada peletakan telur, sumber makanan yang sesuai, tempat berkumpul untuk menemukan lawan jenis dan untuk berlindung.

\section{DAFTAR PUSTAKA}

Departemen Pertanian. 2002. Proyek Pengendalian Hama terpadu perkebunan rakyat. 2002. Musuh Alami Dan Penyakit Tanaman Teh. Jakarta: Direktorat perlindungan perkebunan, Direktorat Jenderal Bina Produksi Perkebunan Departemen Pertanian.

Huffaker \& Messenger. 1989. Theory and Practice of Biological Control. Academic Press, Inc. (London) Ltd., Soeprapto Mangoendiharjo (penerjemah). 1989. Teori danPraktek Pengendalian Biologis. Penerbit:
Universitas Indonesia. Jakarta. Pp. 3-20.

Jumar. 2000. Entomologi Pertanian. Jakarta: PT Rineka Cipta.

Knauer. 1993. Okologie und landwirschaft, situation konflikte. Losungen. Stutgart.

Landis, D. A., Wratten \& G. M. Gurr. 2000. Habitat Management to Conserve Natural Enemies of Arthropoda Pest in Agriculture. Annual Review of Entomology. Vol 45 175-201.

Metcalf, R.L., \& Metcalf, E.L. 1992. Plant Kairomones in Insect Ecology and Control. New York: Chapmann and Hall.

Pracaya. 1991. Hama Penyakit Tanaman. Salatiga: PT Penebar Swadaya.

Rohman, Fatchur. 2008. Struktur Komunitas Tumbuhan Liar dan Arthropoda sebagai Komponen Evaluasi Agroekosistem di Kebun Teh Wonosari Singosari Kabupaten Malang. Disertasi. Tidak diterbitkan. Malang: Universitas Brawijaya.

Ross, H. 1982. A Text Book Entomology. Fourth Edition. New York: John Wiley dan Sons.

Sastroutomo, Soetikno S. 1990. Ekologi Gulma. Jakarta: PT. Gramedia Pustaka Utama.

Sutisna, M., Sastrodiharjo, S., Amidja, D.A.T. 1988. Allelokimia Komunikasi Kimia Antar Organisme. Bandung: Institut Teknologi Bandung.

Untung, K. 1993. Pengantar Pengelolaan Hama Terpadu (edisi kedua). Yogyakarta: UGM Press. 